ent" as opposed to a "future" interest, because no reasonable basis for a distinction appears. ${ }^{26}$ This latter construction would avoid what appears to be a purposeless restriction on the scope of the statute.

Whatever formal objections may be made to the recognition of interests created in favor of strangers, the practical advantages to be derived from liberal application of the statutory rule are obvious. ${ }^{27}$ The instrument is available as evidence of the transaction, and as long as the grantor describes the interest, identifies the recipient, and manifests his own intent with sufficient clarity, there appears no reason to deny his act validity.

\title{
UNIFORM VENDOR AND PURCHASER RISK ACT: EFFECT ON CALIFORNIA LAW
}

Where a contract for the sale of real estate has been signed but prior to transfer of legal title the property is materially damaged by fire or other calamity without the fault of either party, the question arises as to who bears the loss. The cases are in conflict. ${ }^{1}$ As a consequence of the remedy of specific performance, one view regards the purchaser as the equitable owner from the date of the contract and places the risk of loss upon him. ${ }^{2}$ A number of jurisdictions place the risk of loss on the vendor, rejecting the doctrine of equitable conversion as contrary to the intent of the parties. ${ }^{3}$ Under this view the purchaser may refuse performance ${ }^{4}$ and recover any money already paid. ${ }^{5} \mathrm{~A}$ third rule, placing the risk of loss upon the party in possession when loss occurs, has been adopted in the Uniform Vendor and Purchaser Risk Act. This Act provides:

Any contract hereafter made in this State for the purchase and sale of real property shall be interpreted as including an agreement that the parties shall have the following rights and duties, unless the contract expressly provides otherwise:

${ }^{26}$ Support is lent to this view by the use given the term "present interest" in such cases as Leala v. Caroll, supra note 19 , and McGarrigle v. R. C. Orphan Asylum, supro note 18. But of. CaI. CIv. Code $\$ \S 688-691$.

$2 \pi$ This result is recognized by the American Law Institute. Restatement, PropERTY $\$ 472$, comment (b) (1944).

1 See cases collected in Notes (1923) 22 A.L. R. 575; (1926) 41 A.L. R. 1272; (1927) 46 A.I. R. 1126; (1929) 59 A.L.R. 265; (1936) 101 A.L.R. 1241; (1936) 102 A. L. R. 897; (1941) 134 A.L.R. 1093.

2 Keener, The Burden of Loss as an Incident of the Right to the Specific Performance of a Contract (1901) 1 Cor. L. Rev. 1.

3 "But, as between the parties to the contract, to regard the land as converted into personalty before the time for performance of the contract has come is to do violence to their expressed intent." Anderson v. Yaworski (1935) 120 Conn. 390, 394, 181 Atl. 205, 207.

4 Libman v. Levenson (1920) 236 Mass. 221, 128 N. E. 13.

5 Anderson v. Yaworski, supra note 3. 
(a) If, when neither the legal title nor the possession of the subject matter of the contract has been transferred, all or a material part thereof is destroyed without fault of the purchaser or is taken by eminent domain, the vendor cannot enforce the contract, and the purchaser is entitled to recover any portion of the price that he has paid;

(b) If, when either the legal title or the possession of the subject matter of the contract has been transferred, all or any part thereof is destroyed without fault of the vendor or is taken by eminent domain, the purchaser is not thereby relieved from a duty to pay the price, nor is he entitled to recover any portion thereof that he has paid.

This section shall be so interpreted and construed as to effectuate its general purpose to make uniform the law of those states which enact it.

This section may be cited as the Uniform Vendor and Purchaser Risk Act. $^{6}$

California recently became the sixth jurisdiction to enact this legislation.?

\section{The California Decisions:}

The California decisions on the question of who bears the risk of loss have not been consistent. The courts have vacillated as to the appropriate legal theory. In an early case the supreme court by dictum apparently recognized the view placing the loss upon the vendee. ${ }^{8}$ This was not followed in subsequent cases, and, until 1933, it seemed clear that California had adopted the rule placing the risk of loss upon the party in possession. ${ }^{3}$

Uncertainty as to the California rule arose as a result of Kelly v. $S m i t h{ }^{10}$ where the court reviewed the earlier cases and seemed to reaffirm the possession doctrine. The opinion was weakened, however, by the addition of a single sentence: "And in view of the insurance

B 9 U.L.A. 732 (1942). See also 4 WILLISToN, Contracts (rev. ed. 1936) \$§940, 943B; Williston, The Risk of Loss (1895) 9 HaRv. L. Rev. 106.

7 Cal. Stats. 1947, p. 1486, CAL. CIv. CODE $\$ 1662$. Other jurisdictions which have adopted the Uniform Act are: Hawaii (Rev. Laws (1945) \$§ 9281-9283), Michigan (Comp. Laws Supp. (1945) §§ 13354-1-13354-4), New York (REAI Prop. LaW (1945) \$ 240-a), South Dakota (SDC (1939) § 37.1807), Wisconsin (Wis. Stats. 1943, § 235.72). See Comment (1948) 21 So. CaIIF. L. Rev. 177.

$\$$ In Willis v. Wozencraft (1863) 22 Cal. 607, 617-618, the court said, "So much is the vendee considered, in contemplation of equity, as actually seized of the estate, that he must bear any loss which may happen to the estate between the agreement and the conveyance . ..." This statement was, however, dictum, as the point in issue was whether the vendor could recover in ejectment against the purchaser.

o Conlin v. Osborn (1911) 161 Cal. 659, 120 Pac. 755; Smith v. Phoenix Insurance Co. (1891) 91 Cal. 323, 27 Pac. 738; Higbie v. Shields (1915) 27 Cal. App. 536, 150 Pac. 801; Finkbohner v. Glens Falls Ins. Co. (1907) 6 Cal. App. 379, 92 Pac. 318. Contra: Lubarsky v. Chavis (1929) 99 Cal. App. 610, 279 Pac. 205. See Comment (1934) 22 CaLIF. L. REv. 427.

10 (1933) 218 Cal. 543, 24 P. (2d) 471. 
provision in this case it [i.e., the doctrine that the loss should fall upon the party in possession] should be particularly true."11 Thus another element, the agreement to insure, was introduced into the California law, and decisions in subsequent cases have emphasized the importance of such an agreement. ${ }^{12}$

The Uniform Act, adopting the possession rule, would seem to clarify the California law, but questions of interpretation remain.

\section{The Effect of An Agreement To Insure:}

The Uniform Act purports to fix the parties' rights and liabilities in the event that there is a material destruction of the subject matter of the contract only where they have failed expressly to provide otherwise. In view of the California cases emphasizing the effect of an agreement by the vendee to insure the premises, ${ }^{13}$ the question arises whether such an agreement is an express provision in the contract precluding reference to the Act.

It is arguable that such an agreement does fix the rights and liabilities of the parties. Where neither title nor possession has been transferred, an agreement by the vendee to insure the premises against a specified risk may fairly be interpreted as an assumption of that risk by the purchaser. An agreement by the vendee to take out fire insurance, for example, seems tantamount to an agreement that "the purchaser assumes the risk of loss caused by fire."

At first glance it might seem immaterial what view as to risk of loss is adopted; that in any event the vendor is protected where the - purchaser agrees to insure. If the purchaser has insured the premises, the vendor will receive the insurance money. ${ }^{14}$ If the purchaser has failed to insure the premises, it could be argued that he is liable either for the purchase price without deduction, having agreed to assume this risk, or for breach of contract, the measure of damages being the amount of the loss. ${ }^{15}$ The view adopted will, however, make a difference. Frequently the loss will exceed the insured value of the premises, in which case the vendor will not be rendered whole by receipt

11 Id. at 554, 24 P. (2d) at 476.

12 Ware v. Security-First Nat. Bank (1936) 7 Cal. (2d) 604, 609, 61 P. (2d) 936, 938 (alternative holding); Ross v. McDougal (1936) 12 Cal. App. (2d) 172, 55 P. (2d) 574 .

13 Cases cited note 12 supra.

14 The California Real Estate Association Standard Form provides: "The Buyer shall insure the buildings now on said property ... against fire, for not less than $75 \%$ of the value thereof, with some Fire Insurance Company to be approved by the Seller and any loss thereunder shall be paid to the Buyer and the Seller as their intcrests may appear." (Emphasis added.)

15 CAL. Crv. Code \$ 3300; Siegel v. Spear \& Co. (1st Dep’t 1921) 195 App. Div ، 845, 187 N. Y. Supp. 284. 
of the insurance money. ${ }^{16}$ Also, in every case where the destruction is "material," the right of the vendor to specific performance will depend upon which view is adopted. Certainly in the usual case the vendor will prefer performance of the contract to receipt of the insurance money even though the money fully compensates him for the value of the destroyed or damaged premises. ${ }^{17}$

Where the contract requires the purchaser to insure the premises against loss by fire, and some other calamity such as flood or earthquake occurs, it would seem unquestionable that such an agreement could not be considered an express provision placing the risk of loss on the vendee. Suppose, for example, $A$ contracts to sell $B$ his beach house, and $B$ agrees to insure against loss due to fire. Before transfer of title or possession the house is materially damaged by high seas. Under the Uniform Act the vendor bears the loss unless the contract expressly provides otherwise. Perhaps the parties felt the danger of encroachment of the sea was too remote to warrant insurance. ${ }^{18}$ Perhaps the parties merely failed to consider carefully the scope of the covenant to insure. At most it would seen that they impliedly provided that the purchaser should bear this risk; probably the implications are the other way. Placing the risk upon the vendee in this situation, even though the parties may have so intended, would not seen justifiable under the Uniform Act.

The problem is essentially one of draftsmanship, and parties entering into agreements for the sale of realty should expressly provide that the purchaser shall bear the risk of loss from any cause, if that is their intent.

\section{The Materiality of the Destruction:}

When neither title nor possession has been transferred, the Uniform Act provides that the risk falls on the vendor when "all or a material part" of the subject matter has been destroyed. In deciding whether or not loss in any particular instance is material, there will,

10 Thus, in Ross v. McDougal, supra note 12, the property involved was being sold for $\$ 3,500$, and the buyer had agreed to keep the dwelling insured in the sum of $\$ 1,200$.

17 The California Standard Form Fire Insurance Policy provides: "The company will not be liable beyond the actual cash value of the interest of the insured in the property at the time of loss or damage ... ; said cash value to be estimated without allowance for any increased cost of repair or reconstruction by reason of any ordinance or law regulating repair or construction of buildings, and without compensation for loss resulting from interruption of business or manufacture." CAx. INs. CODE $\S 2071$.

18 That the risk of loss from causes other than fire is not as unusual as might be imagined is demonstrated by the cases. Ware v. Security-First Nat. Bank, supra note 12 (encroachment of ocean); Cooper v. Huntington (1918) $178 \mathrm{Cal} .160,172$ Pac. 591 (flood) ; Ogren v. Inner Harbor Land Co. (1927) 83 CaL App. 197, 256 Pac. 607 (condemnation); Ford v. Russell (1930) 13 La. App. 390, 128 So. 310 (encroachment of river) ; Libman v. Levenson, supra note 4 (collapse of wall); Pellegrino v. Giuliani (Sup. Ct. 1922) 118 Misc. 329, 193 N. Y. Supp. 258 (windstorm) ; Capital Savings \& Loan Ass'n v. Convey (1933) 175 Wash. 224, 27 P. (2d) 136 (collapse of floor). 
of course, be many borderline cases. The problem, however, is not new in character, and the courts have had much experience in dealing with it. ${ }^{19}$ The question must be determined in the light of the circumstances of each case. ${ }^{20}$

\section{Effect of the Uniform Act on Remedies:}

Where a material part of the subject matter is destroyed, the Act provides that the vendor "cannot enforce the contract, and the purchaser is entitled to recover any portion of the price that he has paid ...." It has been argued that this language deprives a vendor of the action for breach of contract he might otherwise have. ${ }^{22}$ Suppose property depreciates substantially in value between the signing of the contract and the closing date, and the purchaser then refuses to carry out the contract. A few days after the closing date a fire occurs. Fearing that courts might construe this language as depriving the vendor of his right of action against the purchaser for breach of contract, New York, in adopting the Uniform Act, added a provision expressly stating that neither the vendor nor vendee is deprived of a right to recover for breach of contract. ${ }^{23}$ The Uniform Act should not, even without such a provision, be construed as denying either the vendor or vendee such rights. ${ }^{24}$ The Act clearly contemplates only specific performance; the fact of destruction is irrelevant to an already accrued cause of action for damages for breach of contract.

A further question arises, in the event of material damage before transfer of possession or legal title, as to the right of a vendee to specific performance with an abatement of the purchase price. Again, the Unifornu Act was not designed to settle this problem in any jurisdiction in this regard. ${ }^{25}$ Obviously the purchaser may, if he still desires to go through with the transaction, tender the full purchase price and obtain the damaged property. ${ }^{26}$ But a more difficult question

19 CaL. Crv. Code § 1689; see Conlin v. Osborn, supra note 9 at 664, 120 Pac. at 758; McDorman v. Moody (1942) 50 Cal. App. (2d) 136, 141, 122 P. (2d) 639, 542.

20 Restatearent, Contracts (1932) \& 275 ; Hammond Lumber Co. v. Yeager (1921) $185 \mathrm{Cal} .355,197 \mathrm{Pac}$. 111. The Uniform Act does not expressly cover the situation where there has been an immaterial injury to the premises prior to transfer of title or possession. For a discussion of this question, see text at note 33 infra.

21 CAL. Crv. Code $\S 1662$.

22 SECONd ANNuAL Report of New York Law Revision Commission (1936) p. 780.

23 N. Y. Real Prop. LAw § 240-a.

244 WITtiston, Contracts (rev. ed. 1936) § 943B n. 1.

25 Ibid.

26 An analogous situation was presented to the court in Miller v. Dyer (1942) 20 Cal. (2d) 526, 127 P. (2d) 901 . The seller of real property sought to defend against an action of specific performance brought by the purchaser on the ground that he did not possess a title as complete as the one he had agreed to convey and since he could not get specific performance, neither could the vendee. The court granted the purchaser specific performance and an abatement of the purchase price. See also Ambrose v. Alioto (1944) 65 Cal. App. (2d) 362, 150 P. (2d) 502. 
arises when the vendee seeks specific performance with an abatement of the price. The recent New York case of World Exhibit Corporation v. City Bank Farmers Trust Co. ${ }^{2 \pi}$ illustrates this problem. A private amusement park was sold to its tenants for $\$ 275,000$, the purchaser making a down payment of $\$ 60,000$. The contract provided that the risk of loss due to fire was assumed by the vendor. Prior to the closing date a substantial portion of the premises was destroyed by fire. The vendor received $\$ 153,000$ of insurance for the property destroyed and damaged. The court held that the purchaser was entitled to specific performance with an abatement of the purchase price of $\$ 140,000$, the agreed amount of the loss.

Both the majority and dissenting opinions implied that the Uniform Act, if applicable, barred an action by the vendee for specific performance with an abatement of the purchase price where there has been a material loss. The majority reasoned, however, that the parties had excluded the Act by inserting the provision as to the risk of loss. ${ }^{28}$ The dissenting opinion argued that the parties had merely made express what was provided for by statute, and therefore had not excluded it. ${ }^{29}$ As a construction of the Uniform Act the case is deceptive, because New York has modified the Act by adding the provision: "... if an immaterial part thereof is destroyed without fault of the purchaser ... neither the vendor nor the purchaser is thereby deprived of the right to enforce the contract; but there shall be, to the extent of the destruction ... an abatement of the purchase price." ${ }^{30}$ It seems clear that by expressly providing for specific performance with an abatement where there has been an immaterial loss, the New York legislature impliedly excluded any such right where the loss is material. Though the court does not say so, its construction of the Act as excluding the right seems almost certainly based on this peculiar New York modification. The Uniform Act itself does not require this result. Where it is in force without modification, the New York construction is not in point, and the right to specific performance with abatement in the event of material destruction must be determined as a matter of policy-not by strict interpretation of the Act.

It is generally accepted that the vendee has a right to a just abatement of the purchase price for a slight deficiency in the quality of an estate to compensate him for the vendor's failure to perform his con-

$2 \pi$ (2d Dep't 1946) 270 App. Div. 654, 61 N. Y.S. (2d) 889.

28 If this interpretation be accepted, then the holding of the majority is in accord with prior New York decisions granting specific performance with abatement where the risk has been assumed by the vendor, even though the loss is substantial. Polisiuk v. Mayers (2d Dep't 1923) 205 App. Div. 573, 200 N. Y. Supp. 97.

29 World Exhibit Corp. v. City Bank Farmers Trust Co., supra note 27 at 660, 61 N.Y.S. (2d) at 895.

30 N. Y. ReAI PROR. LAW (1945) \& 240-a. (Emphasis added.) 
tract in full. ${ }^{31}$ Similarly an abatement is generally granted where there has been a slight deficiency in the quantity of an estate. ${ }^{32}$ On these principles a vendee should be entitled to specific performance with an abatement of the purchase price where there has been immaterial damage to the subject matter of the contract. ${ }^{33}$

Where the damage has been "material," a different problem is presented. Although the vendor must bear the risk of loss in the sense that the purchaser could not be forced to accept a conveyance of the premises in a damaged state, it does not follow that the vendor should be forced to convey property at half the contract price. ${ }^{34} \mathrm{~A}$ decree requiring conveyance based on part payment only would be requiring performance of a contract quite different from that contemplated by the parties. ${ }^{35}$ Where, as in the World Exhibit case, the vendor's loss is fully covered by insurance, this is not true as to the vendor; no injustice results here from enforcing the contract with an abatement. ${ }^{36}$ Where there is no insurance, however, this result seems unjust. Although it has been argued that to refuse specific performance with abatement is to give to the vendor an option which it is doubtful the parties intended, ${ }^{37}$ it would seem preferable to regard the question as involving an impossibility of performance, relieving both parties from the obligations of the contract. ${ }^{38}$

\section{Conclusions:}

The adoption of the Uniform Act does not settle all the problems of risk of loss in sales of realty. It should be recognized that competent draftsmanship here can prevent litigation. Contracts for the sale of real property should be drafted with an awareness of the questions which remain unsettled by the Uniform Vendor and Purchaser Risk Act.

31 Miller v. Dyer, supra note 26; Smiddy v. Grafton (1912) 163 Cal. 16, 124 Pac. 433. 32 Seegar v. Smith (1887) 78 Ga. 616, 3 S. E. 613; see Note (1907) 10 L. R. A. (N.s.) 117 .

33 Thus, in those jurisdictions where, regardless of the party in possession, the vendor must bear the loss, it is held that where the loss is immaterial, the vendee cannot rescind but is entitled to an abatement of the purchase price. Capital Savings \& Loan Ass'n v. Convey, supra note 18. As the Act lays down a rule as to risk where the loss is material, it would seem anomalous to adopt a contrary rule where the loss is immaterial. Therefore, it might be argued that, by implication, tbe Act places the risk of an immaterial loss upon the vendor in the sense that the vendee is entitled to abatement.

If the risk is on the vendee because of transfer of possession or title, the Act precludes the right of the vendee to an abatement. Of course, the same result necessarily follows where the contract places the risk of loss upon the vendee.

34 Hawkes v. Kehoe (1907) 193 Mass. 419, 79 N. E. 766.

35 Rudd v. Lascelles (1901) 1 Ch. 815.

36 The New York court, however, did not mention the insurance as bearing on the result.

374 WuIISTON, CoNTRACTS $\$ 935$.

38 Simpson, Legislative Changes in the Law of Equitable Conversion by Contract: II (1935) 44 YALE L. J. 754, 758 et seq. See also Phinizy v. Guernsey (1900) 111 Ga. 346, 36 S. E. 796; Polisiuk v. Mayers, supra note 28. 